\title{
State transformations and welfare models: the significance of the return of public institutions in Ecuador of the Citizen Revolution (2007-2017)
}

\author{
Gemma Ubasart-González \\ Political Science Research Group, University of Girona, Girona, Spain, and \\ Analía Mara Minteguiaga \\ Study Group on Social Policy and Working Conditions, \\ Gino Germani Research Institute, University of Buenos Aires, \\ Buenos Aires, Argentina
}

\begin{abstract}
Purpose - The purpose of this paper is to examine the relation between estate transformations produced during the governments of the Citizen Revolution (CR) in Ecuador (2007-2017) and welfare regime transformations.

Design/methodology/approach - The CR's project registers an array of specificities that make it a relevant case study to understand it. Among them, it articulated the transformation of the development model with a comprehensive state reform: emphasized both the modernization of the state and the productive structure, and the creation of the basic pillars of a welfare state. The ambitious project materialized in an ambivalent manner, revealing accomplishments and limitations.

Findings - The recovery of resources for the state, the efficient organization of resources, decentralization and deconcentration processes, public administration transformations and policy de-corporatization processes accompanied and even propelled important achievements in the social sphere in terms of decommodification, stratification, commodification and defamiliarization. Ecuador's starting point, as a small and impoverished country with pubic and communal goods and services dismantled through neoliberal reforms, was quite precarious. But, progress was made. Beyond the identified limitations, its accomplishments must be highlighted because they are novel in comparison to other progressive government experiences, especially in the context of Central Andean countries.

Originality/value - This article vindicates the need to link state transformation processes to welfare regime transformations, as well as the academic literature that informs both fields. The description of what took place in Ecuador in the field of social welfare during the ten years of the CR continues to confirm the theoretical potential of the concept of welfare regime with the necessary translations and appropriations that allow for the analysis of countries in the region. It enables an approach to a more theoretically and methodologically elusive object that is at the same time tremendously potent in analytical terms and in its contributions to social transformations. An object that alludes to areas gravely affected during neoliberal hegemony, linked to public institutionality, state capacity and state autonomy. This is why everything that affects the state and the management of public goods and services must be incorporated into the analysis.
\end{abstract}

Keywords Latin America, Ecuador, Citizen revolution, State transformation, Welfare regim, Social policy Paper type Research paper

(C) Gemma Ubasart-González and Analía Mara Minteguiaga. Published by Emerald Publishing Limited. This article is published under the Creative Commons Attribution (CC BY 4.0) licence. Anyone may reproduce, distribute, translate and create derivative works of this article (for both commercial and noncommercial purposes), subject to full attribution to the original publication and authors. The full terms of this licence may be seen at http://creativecommons.org/licences/by/4.0/legalcode
State

transformations and welfare models

Received 30 October 2020 Revised 2 March 2021 11 May 2021 Accepted 12 May 2021 
IJSSP

$42,1 / 2$

\section{Introduction: Ecuador under Rafael Correa's administration}

Ecuador is a small Latin American country with a population of a little over 17 million people, located in the northwest of South America. It has an important indigenous and Afro-Ecuadorian presence, allowing its characterization as a multiethnic and multilingual country. Its economic structure has been historically fragile and dependent on core economies, with a development model centered on the exploitation and export of natural resources and agricultural production. The import substitution industrialization (ISI) model - key among other countries of the region during the 1930s and early 1970s - was barely implemented under the exceptional conditions of the oil boom in a tardy, extemporaneous and limited manner (Pérez Sáinz, 1984; Villalobos, 1987). High poverty rates as well as a limited and precarious development of public policy and institutionality required for the establishment of a social state have been a constant for this Andean country. Furthermore, ethnic and cultural inequalities overlap with entrenched socioeconomic inequalities. Thus, in existing welfare regime typologies, Ecuador has been classified as "exclusionary" (Filgueira, 1998; Barba, 2003) or “familiarist” (Martínez Franzoni, 2007).

Ecuador began the new millennium under austerity policies imposed by the Washington Consensus (WC), and more importantly, facing the loss of its monetary sovereignty after dollarizing its economy. These forms of policies adapt to different contexts: their implementation is not the same in every Latin American country. Former low levels of stateness and social resistance are two factors that impact execution levels (Uquillas, 2007; Correa, 2009). Economic contraction and the reduction of social spending increased the levels of poverty, extreme poverty and inequality pushing a section of the population to migrate (Aliaga, 2017). As a result, the 21st century was inaugurated by important episodes of social protest and mobilization. Social discontent with the elites and the political system triggered the development of a high-conflict cycle. The indigenous-led protests of the late 1980s and early 1990s and the rebellion of the so-called forajidos, in the 2005, are expressions of this contentious period of social, political and institutional instability (Ortiz, 2005; Ramírez, 2005).

Rafael Correa, an economics professor, perceived as an outsider won the presidential elections and began his presidency in January 2007. His arrival ushered the beginning of a constituent process that culminated a year later with the approval of Ecuador's new Political Constitution. The 2008 Constitution laid out a roadmap to fulfill an alternative social project (a Living Well, Buen Vivir or Sumak Kawsay society) [1]. The political process advanced during Correa's decade-long tenure, self-defined as the Citizen Revolution (CR), entailed the beginning of a new stage for the country characterized by social, political and institutional stability [2]. This period coincided with a tide of progressive governmental experiences in the region since the beginning of the 21st century, which remained steady since Hugo Chavez's victory in Venezuela (1998) until his third five-year period [3]. They share a critique of austerity policies, a concern for the welfare of the majorities, and bet on the recovery of public goods, although there are important differences between them (Ramírez, 2006).

The CR's project registers an array of specificities that make it a relevant case study (Coller, 2005). Among them, it articulated the transformation of the development model with a comprehensive state reform: emphasized both the modernization of the state and the productive structure, and the creation of the basic pillars of a welfare state [4]. The ambitious project materialized in an ambivalent manner, revealing accomplishments and limitations. The main objective of this article is to analyze whether transformations that occurred in the country in that particular decade were limited to an increase in social spending, coverage or benefits rather than characterized by seeking structural institutional transformations redefining the relation between the state, the market and the citizenry (or, in other words, the transformations of the welfare regime). It undertook the long overdue challenge of (re) building public institutionality, which required enhancing state capacity. This paper's main argument contends that the mutations within the state configuration and those derived in the shape and content of public management enabled the regime's outstanding performance, 
especially if compared with similar cases [5]. This contribution pertains to the "institutional and governance challenges for the implementation and expansion of social welfare programs" axis of this special issue, which aims to analyze the new challenges for the development and consolidation of emerging welfare states.

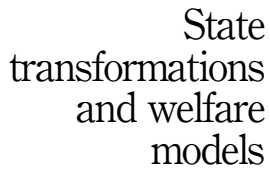

\section{Theoretical and methodological considerations}

\subsection{The return of the state and state capacity}

Neoliberal reforms, or structural adjustments, considerably reduced state capacities and autonomy, especially in the social sphere. External debt, one the most efficient tools of neoliberal pervasion, had a remarkable effect in this respect. As Thwaites Rey (2010) asserts, financial needs led peripheral states to request loans from international financial institutions and creditors. According to the WC, states had to undertake structural reforms and adjustments in the public sector that reduced their room for maneuver in the formulation of their own economic policy to access these loans. Structural adjustment transformed the executive power in mere "transmission belts" of dominant interests, national and foreign (2010, p. 26). The core of public policy, previously defined by national states, began being defined $i$ and $b y$ other organizations.

There is prolific research on the effects of neoliberalism on the region (Sader and Gentili, 2003; Ffrench-Davis, 2005; Basualdo and Arceo, 2006). Among the multiple approaches that inform it, there is special emphasis on the analysis of the economic and social impacts of its core policies: privatizations, de-regulation, labor flexibilization and market liberalization, among others (Agosin and Ffrench-Davis, 1994; De la Garza, 2000). Lesser emphasis was granted to studying the consequences in terms of the quality and sustainability of enacted public policy and of the state's administrative structure (Minteguiaga and Robalino, 2019).

This text aims to recover the debate on state capacity and matters linked to stateness as it relates to the analysis of social welfare, using a specific case study.

There are two main perspectives with different goals in this debate. One used by international organisms and entities that generate information for decision-making and formulate complex indexes that allow for cross-country comparisons on different aspect of state action (e.g. the World Economic Forum, the Bertelsmann Transformation Index or the International Monetary Fund). These center their analysis on political stability, freedom of expression, the presence of conflict and/or the state of intellectual property in different countries and produce studies geared toward market openness: they seek to highlight the potential for doing business in different parts of the world.

And another, more academic perspective, centered in the theoretical and conceptual analysis of state capacity; a political science perspective. This paper will reclaim three major contributions within this perspective. The first analyzes state capacity or stateness through the examination of the resources available to the state. Building upon Weber's contributions, Mann (1984) identifies two types of state power: despotic and infrastructural power. Despotic power refers to that yielded by the elite, to the array of actions the elite is capable of undertaking with no institutionalized negotiation with civil society groups or any other social group. Infrastructural power, exercised in most capitalist democracies, refers to the capacity to penetrate civil society and logistically implement policy decisions throughout a given national territory. In practice, there are innumerable combinations and sequences of despotic and infrastructural power. According to this intellectual current, infrastructural power is interconnected to state autonomy. The second contribution, which stems from the Latin American experience, focuses on state capacity in terms of its territorial presence and interventions. It describes the areas reached by state intervention and those peripheral areas where the state is largely absent, what O'Donnell (1993) called "brown areas." Likewise, this perspective allows for critical consideration of the dire situation of a state that cannot ensure the realization of rights throughout its territory and thus produces "the functional and 
IJSSP

$42,1 / 2$

territorial evaporation of its public dimension" (O'Donnell, 1993, p. 69). That is to say, it elucidates the link between state and citizenry.

Finally, Fernández and García Puente (2012) provide another, more recent, perspective that elaborates on Mann and O'Donnell's contributions and proposes a debate on state capacity as it relates to economic development in the region. Drawing on ideas by Evans (1996), Chibber (2002) and Weiss (2003), the authors explore the importance of the quality of state structures, and consequently its endogenous and relational capacities to implement state public action. This fact implies the need to direct and coordinate other actors, underscoring the risk of particular interests or sectors and power coalitions coopting the state and questioning or threatening the universal scope of its action (2012, p. 35). According to this perspective, connections (not co-optation) among diverse state and non-state actors and between the different intra-state levels are key. In the analysis of Latin American states, Uribe Gómez and Brachet-Márquez (2016) suggest that the historical configuration of relations between state and non-state actors should be considered along with the quality of state structures and the connections among actors.

A methodological approach emerges from this theoretical debate with three dimensions for the analysis of state transformations: (1) state capacity through available power resources: monetary resources available to the state, as well as the institutionality that enables the proper functioning of public goods and services. (2) Territorial presence: the capacity of public action to permeate the entire territory (i.e. the possibility to eradicate "brown areas"). (3) The state's relative autonomy: assessing the state's margin of maneuver with respect to private organisms, of a business or social provenance.

\subsection{Welfare regime literature contributions and its analytical dimensions}

The field of study of social welfare in Latin America acquired renewed relevance in the 1980s, mainly for two reasons: (1) a general interest in comparative regional studies and (2) the analytic potency that the introduction of Gøsta Esping-Andersen's concepts and ideas through his work The Three Worlds Of Welfare Capitalism - produced. Although his contribution focused on a set of developed capitalist countries, it established an original angle to transcend "classical" studies of "welfare states" that had dominated the debate until then.

The concept capable of such transmutation was "welfare regimes," and supporting it, the proposal of a large-scale comparison between countries. The notion of welfare regime alludes to the fact that welfare is not only the result of social improvement policies but also of its effects on employment and the social structure. "To speak of a 'regime' denotes the fact that, in the relation between the state and the economy an array of legal and organizational features are intertwined," allowing for a specific link between the public and the private (Esping-Andersen, 1993, p. 18). The aforementioned acknowledges that in the provision of welfare, there are other spheres beyond the state and state action, namely, the market, the family and the community, or civil society. This implies the recognition that welfare variations between nations are due to qualitatively different arrangements between the various spheres of welfare provision, each with specific ways to comprehend/manage social risk, and with heterogeneous effects on the social configuration.

For Esping-Andersen, these variations in welfare refer to the differences in social rights and social citizenship. And here, we identify a key element in his proposal because these two notions are inevitably associated with the state and a specific state formation. The author argues that if social citizenship is the central idea of the welfare state, this must imply the "concession of social rights" (Esping-Andersen, 1993, p. 41). If social rights are granted a legal and practical condition similar to that of property rights, and if they are granted in the basis of citizenship (which implies terms of equality and universality) and not of the individual's behavior (in the market), this would necessarily suppose the de-commodification of citizens in regards to the market and a status that would dispute or even substitute that of social class 
(1993, p. 41). Thus, de-commodification will occur "when a service is provided as a matter of rights and when a person can make a living without depending on the market" (1993), that is to say, when the realization of social rights and subsistence is removed from the sphere of the market.

The existence of different spheres does not reduce the gravitational role of the state. There are at least three reasons why state action shapes welfare regimes. According to Oszlak and O'Donnell, (1) public policies are the only actions that "have the support of norms of supposedly compulsory compliance and, ultima ratio, of the control of superior means of coercion [, thus] they impact society more extensively than private policies" (2007, p. 568). As Adelantado et al. contend, it is about the "state monopoly on binding collective allocations," that are reflected "in several instruments; mainly, regulatory capacity through law, and resource administration and management processes, programs, and services" (1998, p. 133). In this sense, (2) state policies not only have the capacity to regulate and intervene on their legal field of competence but to impact the other spheres in a unique way. The state has a decisive influence on the "flow of welfare resources" between spheres (1998, p. 142). Finally, and related to the aforementioned, (3) "arbitrariness" (understood not only as discretional actions, but also as founding) is a distinctive characteristic of state policy linked to welfare "not only to introduce or remove a commodity from the mercantile circuit, but also to politically define what is or not a right and what sector of social welfare will deliver" (1998, pp. 143-144, italics ours).

The second dimension of Esping-Andersen's analysis is stratification, which examines the organizational modalities within welfare states that "help determine the articulation of social solidarity, class divisions, and status differentiation" (Esping-Andersen, 1993, p. 81). That is to say, organizational traits that intervene in (1) the degrees in which - as members of a society - we collectively assume responsibility for the lives of others (degrees of solidarity); (2) the particularities and characteristics of the inequality and differentiation generated by welfare states (singularities of inequality in terms of class and status differentiations) (Aguilar and Minteguiaga, 2020). To explain this concept, he suggests that the welfare state "is not only a mechanism that intervenes in the structure of inequality and possibly corrects it, but it is also a stratification system, it is a active force in the ordering of social relations. In this way, policies can (or cannot) generate stratification problems (by class and status), i.e. forms of inequality and difference" (Esping-Andersen, 1993, p. 44). The concept is based on the perceived effects that welfare-oriented state intervention has over the social structure and vice-versa. As Adelantado et al. assert, the relation between state policy and social structure is established in terms of "interaction, bidirectionality, and recursiveness" (1998, p. 151).

This implies that in Esping-Andersen's typology, the labor market assumes a predominant role. This is understandable because his comparative study focused on capitalist-developed countries, where the commodification of labor - that is, people's insertion in formalized labor markets - guarantee adequate levels of social protection. In the case of welfare regimes in Latin America, however, the labor market is relevant in so far as its extension and quality is analyzed.

Since the 1980s, several contributions in the field of social welfare studies were developed in Latin America (Minteguiaga and Ubasart-González, 2017). However, until the appearance of the influential work by Martínez Franzoni (2007), they emphasized two spheres: the state and the market. This led to some blind spots in the comprehension of the region's welfare systems, characterized by weak states in the provision of goods and services, underdeveloped and dependent economies, and highly informal labor markets. This forced other spheres, specifically the family, to take on important responsibility on the provision of social welfare. Taking this into account, the author introduces defamiliarization as a new complementary dimension to elucidate the "availability of unpaid female labor within the social division of labor" (Martínez Franzoni, 2007, p. 12). This concept further enables the study of the welfare provision that allows for the reproduction of life, considering the actors on whom it befalls. It is important to stress that 
IJSSP

$42,1 / 2$

the family is not a neutral sphere, within it critical ruptures and produced and reproduced in the social structure, and public policies are key regulators.

These dimensions have been useful to expand on the performance of welfare regimes. The following operationalization is contextualized in the Latin American reality (Minteguiga and Ubasart-González, 2013). (1) Decommodification. (a) Services that enable the realization of social rights, pillar of welfare provision, especially health and education: assigned resources and coverage and other matters of quality and access (public vs private). (b) The possibility of subsistence. Because of the low levels of protection in the region the concept is restricted to situations of labor dependence: maternity, sickness, disability, old age and unemployment. (2) Stratification. (a) Inequality (class, gender and/or ethnic fractures) and the capacity to minimize them through public policy and political action. (b) Forms of stratification produced by welfare policies (e.g. those related to social security or basic income programs). (3) Commodification: expansion of the labor market (economically active population) and the quality of the labor market (the formal/informal duality and the reach of social security affiliation). (4) Defamiliarization: (a) gender inequality in the social structure, focusing on productive and reproductive labor. (b) Specific issues and the effect of public policy on maternity and care provision on them.

\section{Ecuador: state transformations and shifts in the development model}

In the first decade of the 2000s, the discontent context allowed the emergence of government experiences in that stressed the need to recover the state mechanisms to design and implement substantive policy. However, it was a "revised" version of the return of the state. The reconstruction of the state could not remain within the bounds of a European KeynesianFordist model, highly inspired by Weberian notions. Despite its important achievements in the field of social rights, an outdated and out-of-context copy never works. Thus, it became necessary to think of a new form of governance. It required creating a new form of social participation. It also demanded an interpretation of the state as the responsible actor for the implementation of public policy, and this required the examination not only of the state's relation to economic development and the link between the state and civil society, but also a self-examination, an examination of its capacities to instrument such an agenda for transformation. According to Sánchez and Polga-Hecimovich (2019), the post-neoliberal endeavor that takes place in the country is based on an extensive use of the legalconstitutional framework, an increase in national planning agencies and a bureaucratic growth related to the expansion of services.

The so-called democratic state reform was conceived as an integral institutional reform that, guided by the goal of guaranteeing the population's collective welfare, sought to strengthen state roles abandoned during the neoliberal period (regulation, planning, redistribution and public control). These secured a better functioning market, correcting its self-centered and monopolist tendencies as well as a more effective distribution and universal provision of public goods and services (e.g. the Organic Law for the Regulation and Control of Market Power, approved in October 2011, to limit monopolistic practices; the General Insurance Law of 2016, which regulated the medical insurance sector; the 2016 law that regulates the social security systems for the military and national police, which sought to decorporatize the sector; among others). Likewise, the recovery of the state's margin of maneuver required a new management scheme (efficient, transparent, decentralized, deconcentrated and participatory) to provide greater functional coherence and democratic legitimacy to state interventions.

\subsection{Stateness according to state power resources}

These power resources, which can be despotic or infrastructural, are related to the state's resource appropriation capacity. Thus, the territorial implementation of political decisions 
requires materiality: more and better-organized resources. In the case of the $\mathrm{CR}$, different initiatives are undertaken for the (re)appropriation of resources for the state. First, the renegotiation of external debt through a comprehensive audit that declared certain tranches as illegitimate. This strategy enabled a more balanced agreement with creditors, allowing a reduction of the debt's weight on the national budget from $24 \%$ in 2006 to $4 \%$ in 2012 (SENPLADES, 2013a). Second, the adjustment of several contracts with transnational companies (specifically in the oil and mining sectors) to increase the state's profit margins [6] and the creation and/or reinforcement of public companies in strategic sectors (e.g. hydroelectric plants and refineries) (SENPLADES, 2013b). The country has been historically dependent on the exploitation of natural resources.

And, third, the (re)construction of a more robust and progressive tax system, paired with an active fight against tax evasion and fraud. One of the characteristics of "exclusionary" welfare regimes is the lack of resources that reach the state coffers, hindering the implementation of a social agenda and generating public debt. Furthermore, tax revenue has always represented a small fraction of state revenue. During the CR in Ecuador, new legislation and the institutional strengthening of the Internal Revenue Service (SRI, for its Spanish acronym), Ecuador's tax administration institution, secured and expanded resources from taxes and social contributions (Figure 1).

However, to organize resources effectively, the reconstruction of the state's planning capacity was also necessary. The recovery of the state's capacity to define, regulate and control public policy hinged upon the recovery of its planning capacities. The planning system was enshrined in articles 279 and 280 of the Constitution, and the now-extinct National Secretariat for Planning and Development (Secretaría Nacional de Planificación $y$ Desarrollo [SENPLADES]) [7] became the ministerial-rank organism responsible for ensuring its proper functioning. The transfer of the Undersecretary of Public Investment (Subsecretaria de Inversión Pública) from the Ministry of Finance to SENPLADES was a key institutional reform that signaled a very clear shift: public investment was to be concerned mainly with achieving the objectives laid out by the

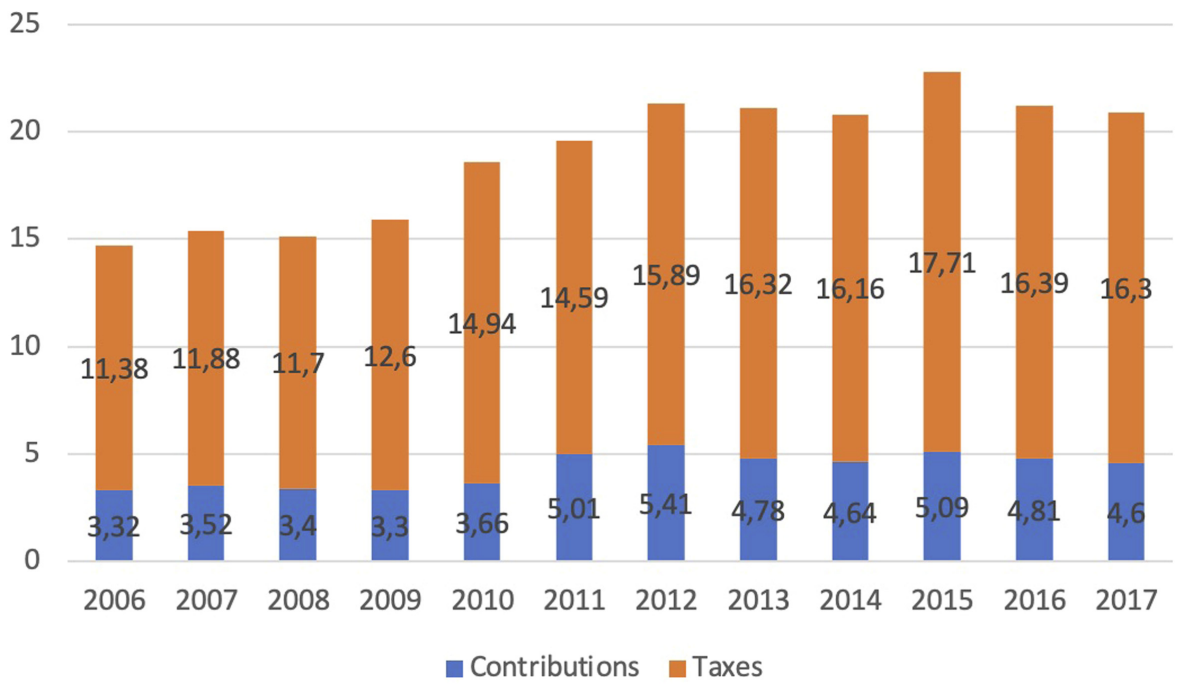

Source(s): CEPALSTAT/CEPAL Data Base and Statistical Publications

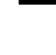


IJSSP

$42,1 / 2$

national development plan and with macroeconomic balance. The executive branch was reorganized, introducing a new institutional architecture, where coordinating ministries as well as SENPLADES guaranteed dynamism in government action, seeking to achieve internal coherence.

\subsection{Stateness as the presence and attention of the state in the territory}

The decentralization and deconcentration process secured state presence in the different territories, chiefly in the most remote areas of the country (in the highlands, the cost, the jungle - Amazon - and the islands - Galapagos) (Larrea, 2012). Unlike during the neoliberal period, this process did not translate into diminished state responsibility or guidance role (Recalde, 2014). The Undersecretariat for the Democratic Reform of the State and Public Management Innovation was created within SENPLADES and tasked with establishing the roles, powers and attributions of each level of government and the necessary sources [8]. This enabled the construction of a typology of competencies susceptible to these processes through which the state's territorial presence was organized and expanded (Type 1, privative, cannot be decentralized; Type 2, high deconcentration and low decentralization; Type 3, high decentralization, low deconcentration; Type 4, strategic sectors) (SENPLADES, 2012, pp. 24-29).

Transformations in public administration. Public institutionality transformations were put in motion through changes in the bureaucratic apparatus. From a Weberian perspective, they sought to develop a state with greater internal coherence (Evan, 1996, p. 534) [9]. These transformations were about providing a solid framework of state authority, regulations and procedures to grant state management legality, certainty and a technical framing (De La Torre, 2013). A review of all public service was essential to this effect. The existing legal dispersion that allowed for exceptional labor regimes according to sectors and institutions had to be addressed. Wage distortions had given origin to a "golden bureaucracy," with wages substantially higher than those of central government workers and other institutions of vital importance for public administration. To solve this, a new law was approved (based on Article 229 of the 2008 Constitution), with the stated mission of "rationalizing" public institutionality and talent management (Peña, 2015, p. 113). Concurrently, innovations in the use of information technologies, with an emphasis on the simplification of procedures, online service provision and document management were introduced to modernize public management. Among them, the following stand out: (1) "Results-Based Government," a tool that gathers all public institution planning, projects and programs, with their corresponding goals and indicators for performance management and evaluation (Reinoso, 2011); and (2) the ISO Quality Certification for public institutions, a methodology based on processes, which implements a quality management system to ensure service quality (Peña, 2015, pp. 116-117).

The creation of a national education and health systems. Within both national systems, the state built a free and universal public network that amplified benefits and territorial coverage. At the same time, state actions were decentralized and deconcentrated, reducing what O'Donnell (1993) defined as "brown-areas." It was more than just allocating more resources to an existing structure; a new structure was designed to guarantee access to these services to all the population. In the case of education, new infrastructure was developed across the territory through the "Millennium Schools." To strengthen the system, the Education Ministry increased teachers' working hours and assigned resources for further training and studies to improve the teaching career: more jobs within the public education system were filled though merits contests, and wages were significantly improved. Enrollment fees were suspended, and the cost-free distribution of textbooks, uniforms and meals was expanded (Minteguiaga, 2011). In the case of healthcare, there is an important extension of the primary care network. Working hour for public health personnel was extended, and wages were 
improved, while gratuity for medications and home-based care services in working-class areas increased (Peña, 2019).

\subsection{Recovery of the state's (relative) autonomy}

The government undertook a de-corporatization process, recovering important degrees of autonomy for public action vis-a-vis interest groups that had guided state action in the past (Resina, 2012; Peña, 2015, 2019; Coronel et al., 2019). Among them, national and international banking and business actors, international financial institutions and non-governmental organizations (NGOs) that had contributed to the neoliberal agenda of limiting state economic interventions and encouraging the state's "disinterest" and "privatization" of welfare policy [10]. In this framework, regulation of the financial sector and restructuring public development banking through the reinforcement of the National Financial Corporation (Corporación Financiera Nacional) and the Bank of the State (Banco del Estado) and the elimination of Central Bank autonomy were key.

The state transformations described faced several relevant pitfalls. It is important to recall contributions made within the study of the state. Bureaucratic state apparatuses are the way in which social relations of domination materialize (state in an abstract sense), and they mutate as these basic social relations change (O'Donnell, 1978). The "legacy of public policy" perspective (Janoski y Hicks, 1994), which reflects on the extent of path dependency, provides a framework to understand the restrictive factors that limit the truly available public policy options in a specific moment. First, many of these processes initially unfolded from structures, agencies and actors with inherited dynamics. The establishment of novel normative orientations toward the recovery of state intervention mechanisms, the creation of new agencies and bureaucratic agents and new modalities for public management operated on what already existed, a status quo strained by the new norms and dispositions that sought to modify it. This implied that some pre-existing bureaucratic dynamics and social policy directions in specific sectors managed to resist.

Second, the responsibility to eradicate the capture and occupation of public spheres for personal or private use does not befall state actors - be they politicians or bureaucrats - alone but also social actors. The invitation for citizen participation had to overcome the corporatist logic of the state, which presented a complex challenge for organized groups accustomed to a corporatist relation with the state (e.g. bankers, indigenous groups, NGOs or public servant groups like the armed forces and the police). As Thwaites Rey asserts, these "hindrances are not circumscribed to dominant sectors, but they are also quite rooted in plebeian practices [...] Achieving participation and consciousness of the most ample plurality of interests and perspectives and promoting a sense of the commons, building institutional capacities to manage the commons and prioritize the general over the particular demands great political and militant efforts" (2010, p. 38).

\section{The welfare regime in Ecuador}

This section applies the listed dimensions in welfare regime studies to deepen the analysis of the case study. It is important to recall that this literature presented a shift in the way that state action was approached. During its first stage, focused on developed countries (EspingAndersen, 1993), it explained the need to emphasize qualitative variables revealing why focusing on quantitative aspects related to spending (amounts, benefits, and coverage) provided a limited lens, not only to understand the state but also the relation between spheres of welfare provision. In Latin America, the incorporation of its specific realities and contexts in research advanced these contributions. As Filgueira indicates "an analyst cannot focus on the 'how' of spending as a typological guide and dismiss the 'how much' when some countries register spending that reaches $18 \%$ of GDP and other do not reach transformations and welfare models 
IJSSP

$42,1 / 2$

32
$8 \%$ " (1998, p. 7). Disparities in spending and coverage are sufficiently significant to warrant detailed attention for these quantitative indicators. This paper seeks to recover the relevance of both points of entry: maintain its gaze on the "how much" while expanding its gaze on the "how".

\subsection{Decommodification: social rights and subsistence}

4.1.1 Social rights: education and health. During the first three years of the CR, social public spending was more than doubled: social public spending as percentage of the GDP goes from $4.2 \%$ in 2006 to $9.3 \%$ in 2016 . On the one hand, this responds to a political prioritization (i.e. allotting more resources for social spending), on the other, it was possible, thanks to the previously described recovery of public resources (i.e. there were more resources to distribute). The expansive economic context must also be taken into consideration. At the same time, as resources increased, there is an expansion in coverage and access to education and health services, as well as their improvement, allowing the massive incorporation of the most marginalized working-class sectors and the realization of their rights. The expansion in access to education and health are related to the increase in social spending, but also with the planned action undertaken by the state: the creation of a national education and health systems. There are several indicators to illustrate this (Figure 2). The extension of coverage and services produced greater public policy efficiency. In comparison to similar countries, like Bolivia and Peru, the advancement of these indicators in Ecuador is quite rapid (Minteguiaga and Ubasart-González, 2021).

Finally, this section is concerned about the quality of the services provided. It seems evident that greater investment and strengthening the guiding and planning capacities of public policy have produced an improvement in the quality of the services. Despite the difficulty to access direct indicators to validate this assertion, there are indirect indicators that show an improvement in subjective assessment of citizens' perception on the quality of public services (ENEMDU-INEC 2008 and 2011). However, there are suspicions that the quality of public services does not reach the expectations of the middle and higher classes. Here lies a challenge: public services should be designed to be able to compete with private providers to have a real process of decommodification in terms of rights.

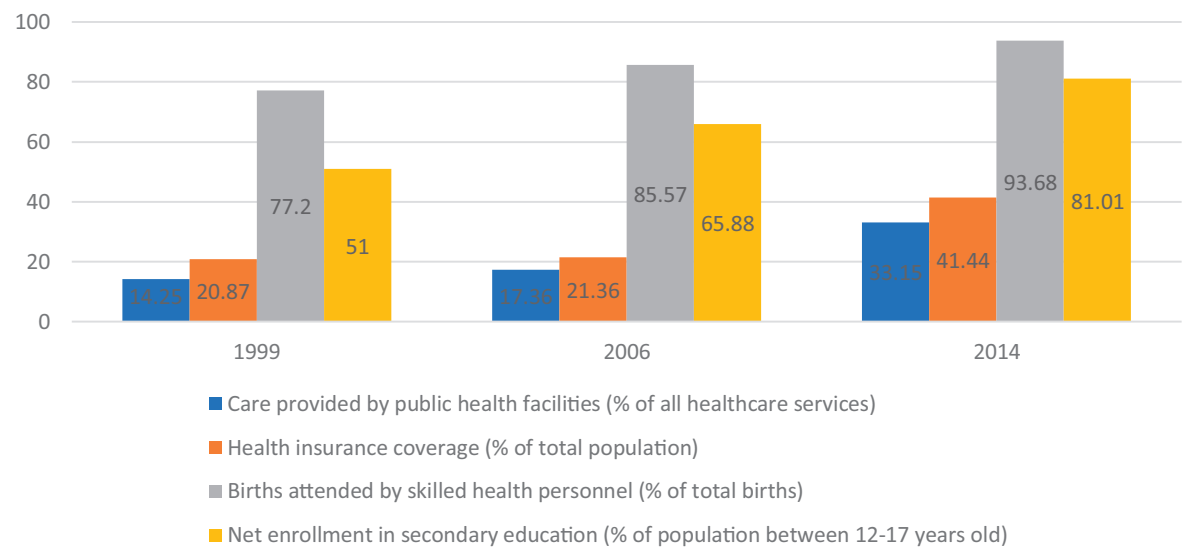

Source(s): INEC- Life-conditions Survey
Figure 2.

Expansion of health and educations services 
4.1.2 Subsistence: contributive and non-contributive benefits. Ecuador's social security system has been historically characterized by a high fragmentation and low coverage (MesaLago, 1985). It is comprised by the Ecuadorian Social Security Institute (Instituto Ecuatoriano de la Seguridad Social, or IESS), which has greater weight and scope, the Peasant Social Security (Seguro Social Campesino, or SSC) and a separate fund for the army (ISSFA, for its Spanish acronym) and for the police (ISSPOL, for its Spanish acronym). They include all the benefits laid out in the International Labor Organization's (ILO's) 102 Convention of 1952, except for unemployment provisions. During its first ten years, the CR took steps to unify and simplify the system: the army and police funds were restructured to make them compatible with the IESS and benefits for rank and file and officers were integrated [11]. Likewise, coverage was expanded through the establishment of a penal responsibility to affiliate workers, a volunteer-based option for self-affiliation, the extension of the SSC [12] and a new pension-scheme exclusively for homemakers that have contributive and non-contributive components delivered by the state [13].

Non-contributive benefits are all those designed from an assistentialist perspective. Most of them have their origin in neoliberal policies based on focalized interventions, although with some reformulations. During the decade of the $\mathrm{CR}$, conditional cash transfers were reorganized to establish a subjective right [14], and a protection system was designed to go beyond specific programs, which had a positive effect on institutionality. The Human Development Bonus (HDB) expanded the range of beneficiaries, increased the amount of the cash transfer and incorporated certain elements that increased the possibilities for beneficiaries to be able to self-sustain themselves (e.g. loans associated to the cash transfer). Three ways to access the same benefit (disability pension, elderly pension and mothers/families beneficiaries of the $\mathrm{HDB}$ ) were established, simplifying non-contributive benefits. The first two pensions have no conditions for access; however, they do require beneficiaries to be under a specific income bracket (under the poverty line) and excluded from the social security system. The three benefits had a unified amount of US\$50 a month (Minteguiaga and Ubasart-González, 2013).

\subsection{Stratification: poverty and inequality}

During the period of the CR in Ecuador, poverty and inequality decreased. Although decreasing rates for monetary poverty was a regional phenomenon during the 2000s, the expansion in the realization of social rights and the reduction of inequality were not homogenous. The latter largely depended on the prevalent political views within the executive branch and, above all, its capacity to transform political aspirations into tangible public policies. The capacity to guide and plan public policies in Ecuador is fundamental to explain its relative success (Minteguiaga and Ubasart-González, 2021) (Figure 3).

Class fractures are not the only to traverse Andean societies. Others are added and superimposed, making social inequalities even more chronic and structural. In Ecuador, there is a relevant ethnic fracture: indigenous and Afro-Ecuadorean peoples have been historically discriminated against, restricting their access to economic, education and health resources, among others (Sánchez, 2017). Despite the overall improvement for these groups, the ethnic gap is still prevalent in many indicators (poverty, education, health, employment, etc.). Another structural fracture is that of gender (see section on familiarization).

\subsection{Commodification: access and quality of labor markets}

Welfare research has placed special emphasis on the concept of commodification: access to labor markets. This article applies a broader definition, which refers not only to economically active population but also to other indicators that reveal the quality of labor markets. The
State
transformations
and welfare
models

33 
IJSSP

$42,1 / 2$

\section{4}

Figure 3.

Evolution of poverty, extreme poverty and Gini index (2007-2016)

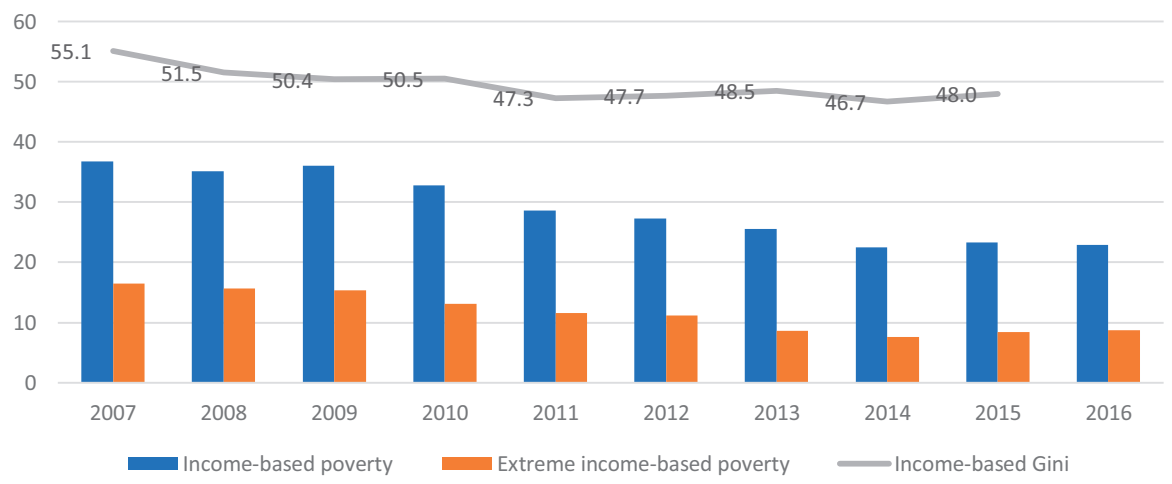

Source(s): INEC-Employment, Unemployment and Underemployment Survey

state can affect the labor market in two ways: through labor regulations and productive policies that seek to transform the production model. Fewer achievements were witnessed in the second, linked to the transformation of the production matrix. Some authors point to the strained relation between the state and the industrial class (Andrade and Nicholls, 2017). Surely, this type of process requires longer-term strategies.

State intervention in companies that epitomized precariousness and exploitation (e.g. banana plantations, shrimp farms, etc.), forcing them to formalize labor relations, and public actions and proclamations to impose the obligation to formalize all paid labor were among the most emblematic actions undertaken during the first years of the CR [15]. The latter was particularly relevant in the domestic realm. Both campaigns were important from a symbolic perspective because they intervened in spaces traditionally conceived as part of the private sphere. Other substantial measures in this area include the recognition of labor rights for Ecuador's migrant population; the increase of the minimum wage and pegging it to the consumer price index; approval of the Organic Law for Public Service, which unified and dignified public servants; approval of the Organic Law for Labor Justice and Recognition of Work in the Home; to modify the Labor Code and the Social Security Law to eliminate fixedterm contracts and replaced the with indefinite-term contracts to guarantee labor stability, limited payment of utilities in the private sector to reduce wage gaps, consolidated utilities per economic sector, limited and regulated salaries for managerial positions, invalidation of unjustified dismissals for pregnant women and union leaders, and the creation of an alternative for the affiliation of homemakers (Figure 4).

Informality continues to be a structural characteristic in Ecuador despite a downward trend (from $75.8 \%$ in 2006 to $64.9 \%$ in 2017). However, the explained measures produced an improvement in certain labor market macro indicators. More workers entered the social security system, which is particularly noteworthy when comparing it with other Central Andean countries (Minteguiaga and Ubasart-González, 2021). Also, recent studies (produced between 2006 and 2016) register an important decrease in the time spent on paid labor - going from an average of $44 \mathrm{~h}$ a week to $39 \mathrm{~h}$ - which indicates a shift toward a less precarious labor context (Ramírez, 2019, pp. 294-295).

\subsection{Defamiliarization: the gender gap}

Women continue to have a central role in sustaining reproductive work. According to data extracted from ECLAC's time-use surveys, women's dedication to unpaid work barely 

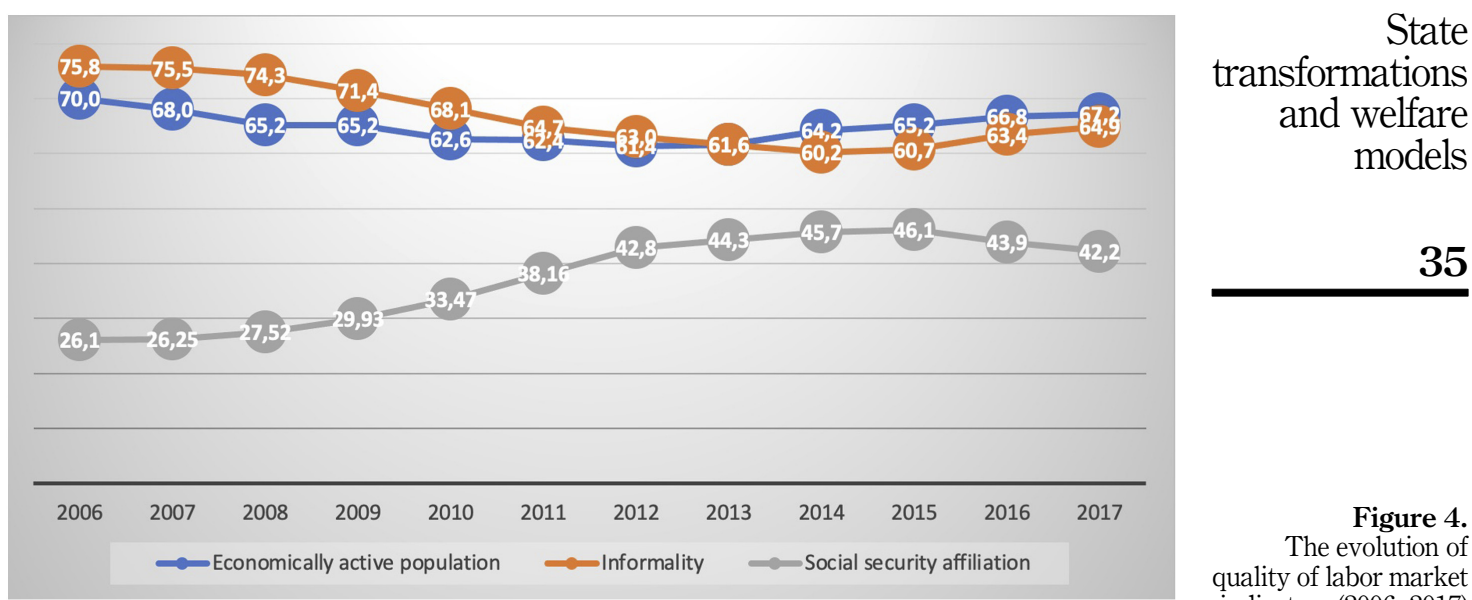

Source(s): ECLAC and EMENDU-INEC (social security affiliation between 2006 and 2013)

decreased in the time period. The percentage of women (15 years old and more) who exclusively dedicate their time to unpaid work in the home went from $28.8 \%$ in 2006 to $26.1 \%$ in 2017. Furthermore, regarding total time destined to work, an important part of work performed by women is disregarded and unpaid, placing them in a worse situation to access resources and services. In 2012, women dedicated $37 \mathrm{~h}$ to unpaid labor and $20.7 \mathrm{~h}$ to paid labor, while men dedicated 9.9 and $44 \mathrm{~h}$, respectively. Another indicator that reveals the unequal familial burden on women in Ecuador is early motherhood. In 2010, 16.95\% of women 15-19 years old were mothers; these numbers are increasing if compared to 2001 numbers. The figure reveals two social problems: lack of access to information and family planning methods and the prevalence of sexual violence against girls.

Investment in welfare policies has helped close the gender gap: more resources in health and education policies have produced improvements in material health and equality in access to education while labor regulations in Ecuador have reduced the gender gap in social security affiliation, which is very small (inexistent in 2012 and 2013). However, some public policies have had ambivalent effects. The Joaquin Gallegos Lara mission, for example, which sought to guarantee a monthly income for impoverished people with disabilities through his or her primary caregiver. On the one hand, it allowed for a degree of de-familiarization because the state begun to assume certain responsibilities of care, but on the other, it might have discouraged the participation of women in the labor market (Minteguiaga and UbasartGonzález, 2014).

There is definitely a two-way challenge: the participation of men and other spheres of welfare provision (the market, state and community) in reproductive work and improvements in access to sexual and reproductive health (Morales, 2020). Matters related to moral and/or religious debates show the least development.

\section{Conclusions}

The CR project sought to establish the pillars of a basic social state by articulating the transformation of the national development model and a comprehensive state reform. The changes on the configuration of the state, which revealed the importance of rethinking the inexorable interrelation between the social and economic/productive realm, exposed the 
IJSSP

$42,1 / 2$

dense social fabric on which governmental legitimacy, not only legal but also performance legitimacy, relies. The latter is linked to the way in which certain results are obtained. It is not the same to reduce poverty and extreme poverty through focalized policies than to do so through the creation of universal education, health and social protection systems. There is a different type of productivity (state performance results) in these modalities of state intervention in the social sphere that has not been fully comprehended. There is a little bit of everything in the policies implemented in Ecuador; however, the focalization vs universalism tension is always present. When the first are designed, they are conceived as a matter of subjective right, thus, from a rights perspective (i.e. subjected to the criteria of needs rather than budget availability).

The present article has examined the relation between state transformations produced during the governments of the $\mathrm{CR}$ in Ecuador and welfare regime transformations. To do this, it has shed light on the process of state recovery and (re)construction throughout reviewing a decade of unprecedented development in the country's social agenda. While some authors have stressed the international context and the commodities boom as explanatory variables (De la Torre et al., 2020), these interpretations neglect the structural reforms undertaken that enabled a higher yield from the efforts to build social citizenship [16]. This paper's reaffirms the importance of applying a complex lens on social welfare analyses, to consider the interaction between spheres of welfare provision and the specificities of the relations between the public-state sphere and the others. Additionally, it invites us to re-evaluate what elements of state intervention must be considered: scrutiny of how much is spent and results in terms of benefits and coverage must be complemented with inquiries on how the realization of social citizenship is structured. There is a productive field of research and work that links state capacity and social citizenship. It exceeds the scope of this article, but one can assert that the relations between public institutionality and social movements have been of cooperation some times and many other times, of contention, generating division within these actors. The centrality of the state and of state power during the Correa administration and the anti-state position of some movements has hindered the construction of productive alliances.

Table 1 identifies the main dimensions of change undertaken during Rafael Correa's tenyear tenure. The recovery of resources for the state, the efficient organization of resources, decentralization and deconcentration processes, public administration transformations and policy de-corporatization processes accompanied and even propelled important achievements in the social sphere. Ecuador's starting point, as a small and impoverished country with pubic and communal goods and services dismantled through neoliberal reforms, was quite precarious. But, progress was made. Beyond the identified limitations, its accomplishments must be highlighted because they are novel in comparison to other progressive government experiences, especially in the context of Central Andean countries.

This article vindicates the need to link state transformation processes to welfare regime transformations, as well as the academic literature that informs both fields. The description of what took place in Ecuador in the field of social welfare during the ten years of the CR continues to confirm the theoretical potential of the concept of welfare regime with the necessary translations and appropriations that allow for the analysis of countries in the region. It enables an approach to a more theoretically and methodologically elusive object that is at the same time tremendously potent in analytical terms and in its contributions to social transformations. An object that alludes to areas gravely affected during neoliberal hegemony, linked to public institutionality, state capacity and state autonomy. This is why everything that affects the state and the management of public goods and services must be incorporated into the analysis. 
State transformations Stateness according to state power resources

Stateness as the presence and attention of the State in the territory

State's (relative) autonomy

The welfare regime transformations
(1) Resources recovery for the state: the renegotiation of external debt; the adjustment of several contracts with transnational companies; construction of a more robust and progressive tax system

(2) Efficient organization of resources associated to public management modernization: reconstruction of the state's planning capacity

(1) The decentralization and deconcentration process

(2) Transformations in public administration: grant state management legality, certainty and a technical framing

(3) The creation of a national education and health systems

De-corporatization process

(1) Social rights. Increase in resources, services, health and education coverage. Quality improvements

(2) Dependency. Simplification of the social security system. Expansion of affiliation with considerable penalties. Expansion of the peasant social security system and inclusion of domestic work. Conditional cash transfers like a subjective right

Stratification

Commodification Inequality and monetary poverty reduction Increase of the economically active population to two-third. Slight reduction in informality. Important increase in social security affiliations Investment in welfare policies ameliorated the gender gap (education, wealth, social security) Deep inequalities in the distribution of reproductive work. Significant challenges on access to sexual and reproductive health

\section{State \\ transformations and welfare models}

De-familiarization

Source(s): Prepared by the authors

Table 1. Dimensions of state and welfare regime transformations

\section{Notes}

1. There is an extensive debate on the inclusion of this concept in the Constitution, legislation and policies implemented by Correa's government (Acosta, 2015; Altmann, 2014; Vanhulst and Beling, 2013; Waldmuller and Rodríguez, 2018). Without furthering the debate, one must recognize that although the construction of a plurinational (multiethnic) state is present in the discourse and normative framework, its effective realization has been more limited than in the Bolivian case. In Ecuador, it has had greater impact in the field of national planning and education, through intercultural education (Cevallos and Bramwell, 2015; Crespo, 2017; Minteguiaga, 2020).

2. In the previous stage, political and economic instability intensified. Seven presidents were formally recognized in a period of only ten years (1996-2006); the three popularly elected governments elected between 1996 and 2003 could not complete their terms as their presidents were removed (Peña, 2019, p. 3).

3. The progressive tendency is reversed when right-wing governments rise to power: 2015 in Argentina, 2016 in Brazil, 2017 in Ecuador, 2019 in Bolivia and 2020 in Uruguay.

4. The main innovations take place during Correa's first and second terms (2007-2009 y 2009-2013, respectively); when national planning instruments and state reform initiatives had greater guiding weight on policy (SENPLADES, 2007, 2009). 
IJSSP

$42,1 / 2$

38

5. A comparative analysis of the Ecuadorian case vis-à-vis Peru and Bolivia can be found in Minteguiaga and Ubasart-González (2021).

6. In 2010, with the approval of the Organic Law on Planning and Public Finance (Código Orgánico de Planificación y Finanzas Públicas), oil revenue was integrated in a definitive way to the state's general budget.

7. SENPLADES extinguished by Decree 732, Official Registry 496, Supplement, of May 28, 2019.

8. There are analysis on the progress and limitations of deconcentration processes; however, they are specific case studies (e.g. Praga-Trigo, 2017). There are not quantitative and qualitative studies that include the whole country.

9. There were several of these processes in Ecuador that required legal reforms to unify, professionalize and dignify public workers. The case study on the Revenue Service (Servicio de Rentas Internas or SRI) (Nieto, 2018) is an example.

10. This process reached the boards of public companies and of regulatory bodies for strategic sectors such as communications a, electricity, and oil among others.

11. Law to Strengthen the Special Social Security Regimes for the Armed Forces and the Police of October 21, 2016. Official registry n. 867.

12. Law Reform to the Social Security Law of November 18, 2010. Official registry n. 323.

13. The Organic Law for Labor Justice and Recognition of Work in the Home of April 20, 2015. Official registry n. 483.

14. Through a data cleansing process ("improvements" in focalization), Ecuador reached coverage of $95 \%$ of all household living in poverty (MCDS, 2010).

15. The Referendum of May 2011 enquired about labor obligations. See: http://www.funcionjudicial. gob.ec/www/pdf/baselegal/Consulta \%20Popular\%20y\%20Referendum.PDF.

16. See section 3.1. and Ramírez (2017, pp. 16-17, 64-65).

\section{References}

Acosta, A. (2015), "El Buen Vivir como alternativa al desarrollo. Algunas reflexiones económicas y no tan económicas", Política y sociedad, Vol. 52 No. 2, pp. 299-330.

Adelantado, J., Noguera, J.A., Rambla, X. and Sáez, L. (1998), "Las relaciones entre estructura y política sociales: una propuesta teórica”, Revista Mexicana de Sociología, Vol. 60 Nos 3, pp. 123-156.

Agosin, M. and Ffrench-Davis, R. (1994), La liberalización comercial en América Latina, Revista de la CEPAL, CEPAL, Santiago de Chile, pp. 41-62.

Aguilar, P. and Minteguiaga, A. (2020), "Una renovada apelación al bienestar: entre el neoliberalismo y pandemia”, Revista Cátedra Paralela, No. 17, pp. 17-37.

Aliaga, F. (Ed.), (2017), Migraciones internacionales. Alteridad y procesos sociopoliticos, Ediciones USTA, Bogotá.

Altmann, P. (2014), "Good life as a social movement proposal for natural resource use: the indigenous movement in Ecuador", Consilience, Vol. 12, pp. 82-94.

Andrade, P. and Nicholls, E. (2017), "La relación entre capacidad y autoridad en el Estado: La construcción de un Estado 'Excepcionalista' en Ecuador", European Review of Latin American and Caribbean Studies, Vol. 103, pp. 1-24.

Barba Solano, C. (2003), "El nuevo paradigma de bienestar residual y deslocalizado. Reforma de los regímenes de bienestar en la OCDE”, PhD dissertation, Universidad de Guadalajara, América Latina y México.

Basualdo, E. and Arceo, E., (comps.) (2006), Neoliberalismo y sectores dominantes. Tendencias globales y experiencias nacionales, CLACSO, Buenos Aires. 
Cevallos Estarellas, P. and Bramwell, D. (2015), "Ecuador, 2007-2014: attempting a radical educational transformation", in Schwartzman, S. (Ed.), Education in South America, Bloomsbury Academic, London, pp. 329-361.

Chibber, V. (2002), "Bureaucratic rationality and the developmental state", American Journal of Sociology, Vol. 107 No. 4, pp. 951-989.

State
transformations
and welfare
models

Coller, X. (2005), Estudio de casos, Cuadernos Metodológicos, No. 30, CIS, Madrid.

Coronel, V., Stoessel, S., Guanche, J.C. and Cadahia, M.L. (2019), "Captura y descorporativización estatal de las élites financieras en Ecuador", Colombia Internacional, Vol. 100, pp. 147-174, doi: 10.7440/colombiaint100.2019.07.

Correa, R. (2009), Ecuador: de Banana Republic a la No República, Random House, Quito.

Crespo Burgos, C. (2017), "Transformaciones educativas en Ecuador y Bolivia (2005-2013). Escenarios en disputa y nuevos sentidos para la educación (sumak kawsay/suma qamaña)", Tesis Doctorado, Universidad Federal de Minas Gerais.

De la Garza Toledo, E., (comp.) (2000), Reestructuración productiva, mercado de trabajo y sindicatos en América Latina, CLACSO, Buenos Aires.

De La Torre, P. (2013), Los constructores del Estado Nacional 1830-2010. En el cerebro politico del Ecuador, SENPLADES/El Telégrafo, Quito.

De la Torre, A., Cueva, S. and Castellanos-Vásconez, M.A. (2020), "The macroeconomics of the commodities boom in Ecuador: a comparative perspective", in Sánchez, F. and Pachano, S. (Eds), Assessing the Left Turn in Ecuador, Palgrave, London, pp. 163-213.

Esping-Andersen, G. (1993), Los tres mundos del Estado del Bienestar, Alfons el Magnànim, València.

Evans, P. (1996), "El Estado como problema y solución”, Revista Desarrollo Económico, Vol. 35 No. 140 , pp. 529-562.

Fernández, R. and García, J. (2012), "Revisando el Estado: perspectivas y lineamientos para el desarrollo latinoamericano", Revista Perfiles Latinoamericanos, Vol. 20 No. 40, pp. 35-61.

Ffrench-Davis, R. (2005), "Reformas para América Latina después del fundamentalismo neoliberal”, in Serie Economía, CEPAL, Santiago de Chile.

Filgueira, F. (1998), "El nuevo modelo de prestaciones sociales en América Latina: eficiencia, residualismo y ciudadanía estratificada", in Roberts, B. (Ed.), Ciudadanía y Política Social, FLACSO/SSRC, San José, pp. 71-116.

Janoski, T. and Hicks, A.M. (1994), The Comparative Political Economy of Welfare State, Cambridge University Press, Cambridge.

Larrea, A.M. (2012), Modo de desarrollo, organización territorial y cambio constituyente en el Ecuador, SENPLADES, Quito.

Mann, M. (1984), "The autonomous power of state: its origins, mechanisms and results", European Journal of Sociology, Vol. 25 No. 2, pp. 185-213.

Martínez Franzoni, J. (2007), Regímenes de Bienestar en América Latina, Fundación Carolina, Madrid.

Ministerio Coordinador de Desarrollo Social (2010), Programas Sociales 2010, MCDS, Quito.

Mesa-Lago, C. (1985), El Desarrollo de la Seguridad Social en América Latina, Estudios e Informes No. 43, CEPAL, Santiago de Chile.

Minteguiaga, A. (2011), Reflexiones en torno a la violencia en y desde la escuela en Ecuador entre la invisibilización y el silencio institucional, EDNA-UNICEF, Quito.

Minteguiaga, A. (2020), "Reformas curriculares en el Ecuador reciente (1980-2017): entre las influencias globales y los esfuerzos por un proyecto soberano", in Díaz-Barriga, A. and JiménezVásquez, M. (coords.), Reformas curriculares en educación básica en América Latina. El inicio del siglo XXI (1990-2015), GEDISA/UATx, Ciudad de México, pp. 237-350.

Minteguiaga, A. and Robalino, I. (2019), "La dimensión estatal en los proyectos progresistas de Venezuela, Bolivia y Ecuador: Revisión sistemática de la literatura y agenda para futuras 
IJSSP

$42,1 / 2$ investigaciones", Ponencia XXXVII International Congress of the Latin American Studies Association (LASA), mayo de 2019, Boston, EEUU.

Minteguiaga, A. and Ubasart González, G. (2017), "Esping-Andersen en América latina el estudio de los regímenes de bienestar", Política y Gobierno, Vol. XXIV No. 1, pp. 213-236.

Minteguiaga, A. and Ubasart-González, G. (2013), "Revolución ciudadana y régimen de bienestar en el Ecuador (2007-2012)”, Informe Final de investigación, Repositorio CLACSO.

Minteguiaga, A. and Ubasart-González, G. (2014), "Menos mercado, igual familia”, Revista Íconos, No. 50, pp. 77-96.

Minteguiaga, A. and Ubasart-González, G. (2021), "Reviewing exclusionary welfare regimes: Andean countries (Bolivia, Ecuador and Peru)", in Sátyro, N., Midaglia, C. and Del Pino, E. (Eds), Latin American Social Policy Developments in the Twenty-First Century, Palgrave Macmillan/Springer.

Morales, M. (2020), "A revolution with a female face? Gender debates and policies during Rafael Correa's government", in Sánchez, F. and Pachano, S. (Eds), Assessing the Left Turn in Ecuador, Palgrave, London, pp. 115-13.

Nieto, G. (2018), “Componentes weberianos de los burócratas cercanos al ciudadano y su incidencia en el desempeño institucional: el caso del Servicio de Rentas Internas (SRI) en el Ecuador entre 2014-2017”, Public Management Master dissertation, Instituto de Altos Estudios Nacionales.

O’Donnell, G. (1993), “Estado, Democratización y ciudadanía”, Revista Nueva Sociedad, No. 128, pp. 62-87.

Ortiz, G. (2005), “La acción de los 'forajidos', desafío para los partidos politicos, La Tendencia”, Revista de Análisis Político, No. 3, pp. 23-32.

O’Donnell, G. (1978), "Estado y Clases Sociales en América Latina (2)”, Revista Mexicana de Sociología, Vol. 40 Nos 4, pp. 1157-1199.

Oszlak, O. and O’Donnell, G. (2007), "Estado y políticas estatales en América Latina: hacia una estrategia de investigación", in Acuña, C. (comp.), Lecturas sobre el Estado y las políticas públicas: Retomando el debate de ayer para fortalecer el actual, Jefatura de Gabinete de Ministros de la Nación Argentina, Buenos Aires, pp. 555-584.

Pérez Sáinz, J. (1984), "Industrialización y fuerza de trabajo en Ecuador", Boletín De Estudios Latinoamericanos y Del Caribe, No. 37, pp. 19-43.

Peña, A. (2015), “¿Hacia un Estado meritocrático? Las tensiones del cambio en el Ecuador de la Revolución Ciudadana”, Nueva Sociedad, No. 257, pp. 107-120.

Peña, A. (2019), "Reforma estatal y capacidad institucional: Análisis de la atención primaria de salud en Ecuador (2008-2016)", PhD dissertation, Universitat Autònoma de Barcelona.

Prada-Trigo, J. (2017), "Governance and territorial development in Ecuador: the Plan Nacional del Buen Vivir in Zaruma, Piñas and Portovelo", Journal of Latin American Studies, Vol. 49 No. 2, pp. 299-326.

Ramírez, F. (2005), La insurrección de abril no fue solo una fiesta, Taller el colectivo, Quito.

Ramírez, F. (2006), "Mucho más que dos izquierdas”, Nueva Sociedad, Vol. 205, pp. 30-44.

Ramírez, R. (2017), La gran transición, en busca de nuevos sentidos communes, CIESPALUNESCO, Quito.

Ramírez, R. (2019), "La vida y el tiempo. Apuntes para una teoría ucrónica de la vida buena a partir de la historia reciente del Ecuador", $\mathrm{PhD}$ dissertation, CIS-Universidade de Coimbra.

Recalde, E. (Ed.), (2014), Construcción de un Estado Democrático para el Buen Vivir: Análisis de las principales transformaciones del Estado ecuatoriano 2007-2012, SENPLADES, Quito.

Reinoso Navarro, M. (2011), La gestión pública institucional y el gobierno por resultados, IAEN, Quito.

Resina, J. (2012), "Estado, plurinacionalidad y pueblos indígenas en el Ecuador contemporáneo", Revista pueblos y fronteras digital, Vol. 7 No. 14, pp. 238-268, doi: 10.22201/cimsur.18704115e.2012.14.105.

Sánchez, J. (2017), "Política educativa y protección social: convergencia interna y etnicidad en el Ecuador, 2007-2014”, PhD dissertation, Universitat Autònoma de Barcelona. 
Sader, E. and Gentili, P., (comps.) (2003), La trama del neoliberalismo. Mercado, crisis y exclusión social, CLACSO, Buenos Aires.

Sánchez, F. and Polga-Hecimovich, J. (2019), "The tools of institutional change under post-neoliberalism: Rafael Correa's Ecuador", Journal of Latin American Studies, Vol. 51 No. 2, pp. 379-408.

SENPLADES (2007), Plan Nacional de Desarrollo 2007-2010, SENPLADES, Quito.

SENPLADES (2009), Plan Nacional del Buen Vivir 2009-2013, SENPLADES, Quito.

SENPLADES (2012), Reforma Democrática del Estado. Rediseño de la Función Ejecutiva: de las Carteras de Estado y su Modelo de Gestión, y de la Organización Territorial. Acercando el Estado a la Ciudadanía, SENPLADES, Quito.

SENPLADES (2013a), Atlas de las Desigualdades Socioeconómicas del Ecuador, SENPLADES, Quito.

SENPLADES (2013b), Empresas públicas y planificación: Su rol en la transformación social y productive, SENPLADES, Quito.

Thwaites Rey, M. (2010), "Después de la globalización neoliberal ¿Qué Estado en América Latina?”, Observatorio Social de América Latina, Vol. XI, No. 27bril, pp. 19-43.

Uquillas, A. (2007), El fracaso del neoliberalismo en el Ecuador y alternativas frente a la crisis, EDUMED, Quito.

Uribe Gomez, M. and Brachet-Márquez, V., (coords.) (2016), Estado y Sociedad en América Latina: acercamientos relacionales, COLMEX, México.

Vanhulst, J. and Beling, A.E. (2013), "Buen vivir: la irrupción de América Latina en el campo gravitacional del desarrollo sostenible”, Revista Iberoamericana de Economía Ecológica, Vol. 21, pp. 1-14.

Villalobos, F. (1987), La industrialización ecuatoriana y la utilización de los recursos productivos: 19761983, FLACSO-CIPAD, Quito.

Waldmuller, J. and Rodríguez, L. (2018), "Buen vivir and the rights of nature”, in Jay Drydyk, J. and Keleher, L. (Eds), Handbook of Development Ethics, Routledge, New York, pp. 234-247.

Weiss, L. (2003), States in the Global Economy, Cambridge University Press, Cambridge.

\section{About the authors}

Gemma Ubasart-González is a $\mathrm{PhD}$ in Political Science (Autonomous University of Barcelona - Spain), Associate Professor, Political Science Research Group, University of Girona (Spain). Gemma UbasartGonzález is the corresponding author and can be contacted at: gemma.ubasart@udg.edu

Analía Mara Minteguiaga is a Ph.D. in Social Science Research with specialization in Political Science (FLACSO-México), Researcher of the Study Group on Social Policy and Working Conditions of the Gino Germani Research Institute (GEPSyCT-IGG), University of Buenos Aires. http://polsocytrabiigg. sociales.uba.ar/

For instructions on how to order reprints of this article, please visit our website:

www.emeraldgrouppublishing.com/licensing/reprints.htm

Or contact us for further details: permissions@emeraldinsight.com 